\title{
ORAL CORRECTIVE FEEDBACK IN EFL/ESL CLASSROOMS: CLASSIFICATION MODELS
}

\author{
Pham Thi Hanh*, Pham Xuan Tho \\ Faculty of Linguistics and Cultures of English-speaking Countries, VNU University of Languages \\ and International Studies, Pham Van Dong, Cau Giay, Hanoi, Vietnam
}

Received 28 July 2018

Revised 26 September 2018; Accepted 27 September 2018

\begin{abstract}
Corrective feedback in general, and oral corrective feedback (OCF) in particular, has been of interest to both language teachers and researchers in second language acquisition (SLA). Teachers focus more on positive feedback and concern if corrective feedback should be provided, and when and how to provide it (Ellis, 2017). By comparison, SLA researchers pay attention to negative feedback and its effectiveness. Having received great interest, there have been a number of attempts in defining and classifying OCF up to date. Different models of classification have been proposed with different aspects of OCF taken into consideration, namely implicitness/explicitness and input-providing and output-prompting. This paper aims to review a body of literature on OCF classification models in the field of SLA.
\end{abstract}

Keywords: oral corrective feedback, classification, second language acquisition

\section{Introduction}

Feedback is one of the features of instruction which has been the subject of second language acquisition (SLA) research for decades. Feedback can be positive or negative, depending on whether the feedback giver wants to encourage or reward the hearer, or to correct his/her errors. Corrective feedback, or negative feedback, is a term employed to refer to the "feedback that learners receive on the linguistic errors they make in their oral or written production in a second language [L2]" (Sheen \& Ellis, 2011, p. 593). Research on feedback experienced a boom after Truscott (1996) claimed that corrective feedback had no effect and played no beneficial role in L2 learners' linguistic development. His study generated long standing debates on

* Corresponding author. Tel: 84-1636163003

Email: hanhtpham@gmail.com the issue, leading to a growth in research in this area which, to date, has produced varied findings. Many researchers were quick to reject Truscott's proposal outright. However, a convincing argument for the facilitative role of OCF in L2 acquisition has established by the outcomes of the multitude of research studies on OCF, from the early studies of authors such as Chaudron (1977) and Carroll and Swain (1993) to the more recent studies such as those of Yang and Lyster (2010), Gooch, Saito, and Lyster (2016). These studies have confirmed that negative evidence is beneficial for language learning as the effectiveness of OCF has been found in almost all of them (see recent meta-analyses, e.g. Li, 2010; Lyster \& Saito, 2010; Lyster, Saito, \& Sato, 2013).

Corrective feedback has been of interest to both language teachers and researchers in second language acquisition. Teachers focus more on positive feedback and concern if 
corrective feedback should be provided, and when and how to provide it (Ellis, 2017). By comparison, SLA researchers pay attention to negative feedback and its effectiveness. Corrective feedback can also be classified as written corrective feedback and oral corrective feedback. It has been observed that Vietnamese teachers of English seem to be more concerned and familiar with the pedagogical aspect of corrective feedback, that is, which mistake to be corrected and how to be corrected (Nguyen, 2003). They do not seem to know well and practice the OCF types from cognitive perspective in SLA; the teachers were observed to mostly use only metalinguistic information and elicitation (Le, 2011) while there are many more than that, and they were hardly aware of the fact that clarification requests can serve as corrective feedback (Pham, 2018).

For the reasons above, this paper aims to introduce a review of OCF classification models in the history of OCF and discusses the issues raised from these models. The paper then concludes by pointing out the practical application of these models in the areas of language teaching and SLA theory as well.

\section{Models of OCF classification}

\subsection{Lyster and Ranta (1997)}

An early and influential attempt at establishing a list of oral feedback types was made in the large-scale descriptive study of French immersion classes by Lyster and Ranta (1997). Their study aimed to identify the types of CF that emerged during classroom interactions. The results revealed six types of individual feedback used by the teacher in this study. To illustrate the types, let us look at the different ways a teacher can respond to the following erroneous utterance "she has cat" made by a student, using one of the six following corrective feedback moves.
1. Explicit correction is the teacher's provision of the correct form with such phrases as "Oh, you mean...." "You should say..."

T: You should say, "She has a cat".

2. Recast describes the teacher's reformulations of all or part of the student's erroneous response, which is repeated with change or with both change and emphasis. Translation is also considered a form of recast because, according to the authors, translation occurs infrequently and has similar functions as recasts.

\section{T: She has a cat. / A cat.}

3. Clarification request is a way with which the teacher indicated that he/she could not understand the utterance because of either the meaning or linguistic form. A clarification request includes phrases such as "Pardon me?" or a repetition of the error as in "What do you mean by X?"

\section{T: Pardon?}

4. Metalinguistic feedback is the method the teacher uses to offer comments, information, or questions, about the rules of grammar in the utterance, without an explicit provision of the correct form. These can be metalinguistic comments, e.g. No, not that, and metalinguistic information, e.g. It needs an article, or metalinguistic questions, e.g. Does the noun need an article?

T: No, not "has cat". You need an article “a”, "an" or "the" before a noun

5. Elicitation includes at least three techniques the teacher uses to directly elicit correct form from the student.

a. Completion: The teacher elicits completion from the student as s/he pauses for the student filling in the rest of her utterance. A metalinguistic comment can come before the completion. 
T: No, it's not correct. She has.......

b. Questions: The teacher uses questions to elicit correct forms. It is notable that yes/no questions are excluded; they are metalinguistic feedback.

\section{T: How do we say that in English?}

c. Request for reformulation: The teachers sometimes requests for the student's correction.

$\mathrm{T}$ : Could you correct your sentence?

6. Repetition is the way the teacher repeats the student's incorrect utterance, normally with intonation to highlight the error.

T: She has cat?

Repetition could appear in all other feedback types except for recasts, i.e.

Clarification requests: What do you mean by $X$ ?

Metalinguistic feedback: No, not $X$. We don't say $X$ in French.

Elicitation: How do we say $X$ in French?

Explicit correction: We don't say $X$ in French; we say $Y$.

It can be seen that this early model by Lyster and Ranta (1997) displays one of the early attempts in pinpointing the potential individual OCF types, which set a strong foundation for the later models. These later models, developed from the one by Lyster and Ranta (1997), examine these individual OCF types by categorising them from different perspectives.

\subsection{Ranta and Lyster (2007)}

Ten years after their initial attempt in determining the six possible individual OCF types used by teachers in the descriptive model in 1997 (see section 1 above), Ranta and Lyster (2007) made another move by categorising these OCF moves into reformulations and prompts two groups (see Table 1). As defined by the authors, reformulations include two individual OCF types, recasts and explicit correction, providing learners with target reformulations; prompts, on the other hand, include elicitation, metalinguistic clues, clarification requests and repetition, which signal students to self-repair. The main difference between reformulations and prompts is that while reformulations offer the correct form, prompts withhold it and provide clues for students to produce the correct form from their memory.

Table 1. Classifications of OCF (Ranta and Lyster, 2007)

\begin{tabular}{|c|c|}
\hline REFORMULATIONS & $\begin{array}{c}\text { Recast } \\
\text { Explicit correction }\end{array}$ \\
\hline & Elicitation \\
Metalinguistic clue \\
Clarification \\
request \\
& Repetition \\
\hline
\end{tabular}

This model develops in the way the individual OCF types are categorised, not the number of the OCF types. Sheen and Ellis (2011) made another attempt to both introduce new types of OCF and categorise them at the same time as presented in the next section.

\subsection{Sheen and Ellis (2011)}

Sheen and Ellis's (2011) taxonomy continues to keep the six OCF types introduced by Lyster and Ranta (1997) and the categorisation by Ranta and Lyster (2007) but presents some new features as follows: 
Table 2. A taxonomy of OCF strategies (Sheen and Ellis, 2011, p. 594)

\begin{tabular}{|c|c|c|}
\hline & IMPLICIT & EXPLICIT \\
\hline \multirow{3}{*}{$\begin{array}{c}\text { INPUT- } \\
\text { PROVIDING }\end{array}$} & \multirow{3}{*}{$\begin{array}{l}\text { Conversational recasts (i.e., } \\
\text { the correction consists of a } \\
\text { reformulation of a student } \\
\text { utterance in the attempt to resolve } \\
\text { a conversational problem; such } \\
\text { recasts often take the form } \\
\text { confirmation checks where the } \\
\text { reformulation is followed by a } \\
\text { question tag as in "Oh, so you } \\
\text { were sick yesterday, were you?"). }\end{array}$} & $\begin{array}{c}\text { Didactic recasts (i.e. the correction takes } \\
\text { the form of a reformulation of a student } \\
\text { utterance even though no communication } \\
\text { problem has arisen). }\end{array}$ \\
\hline & & $\begin{array}{l}\text { Explicit correction only (i.e., the } \\
\text { correction takes the form of a direct } \\
\text { signal that an error has been committed } \\
\text { and the correct form is supplied). }\end{array}$ \\
\hline & & $\begin{array}{l}\text { Explicit correction with metalinguistic } \\
\text { explanation (i.e. in addition to signalling } \\
\text { an error has been committed and } \\
\text { providing the correct form, there is also a } \\
\text { metalinguistic comment). }\end{array}$ \\
\hline \multirow{3}{*}{$\begin{array}{c}\text { OUTPUT- } \\
\text { PROMPTING }\end{array}$} & $\begin{array}{l}\text { Repetition (i.e. the learner's } \\
\text { erroneous utterance is repeated } \\
\text { without any intonational } \\
\text { highlighting of the error). }\end{array}$ & $\begin{array}{l}\text { Metalinguistic clue (i.e. a brief } \\
\text { metalinguistic statement aims at eliciting } \\
\text { a correction from the learner). }\end{array}$ \\
\hline & \multirow{2}{*}{$\begin{array}{c}\text { Clarification requests (i.e. } \\
\text { attention is drawn to problem } \\
\text { utterance is repeated by the } \\
\text { speaker indicating/he/she has not } \\
\text { understood it). }\end{array}$} & $\begin{array}{c}\text { Elicitation (i.e. an attempt is made to } \\
\text { verbally elicit the correct form from the } \\
\text { learner by, for example, a prompting } \\
\text { question). }\end{array}$ \\
\hline & & $\begin{array}{l}\text { Paralinguistic signal (i.e. an attempt is } \\
\text { made to non-verbally elicit the correct } \\
\text { form from the learner). }\end{array}$ \\
\hline
\end{tabular}

First, there are nine individual OCF types in this taxonomy instead of six as introduced by Lyster and Ranta in their 1997 and 2007 models. Regarding recasts which are only one type by Lyster and Ranta, this feedback is categorised into two types by Sheen and Ellis. Conversational recasts are considered more implicit, that is, when the teacher does a confirmation check with reformulation followed by a question tag to resolve the communication problem. For example:

\section{$\mathrm{S}$ : She is sick yesterday.}

T: Oh, she was sick, wasn't she?

On the other hand, didactic recasts are more explicit, that is, the teacher reformulates the learner's erroneous utterance even when it is well-understood. For example:

S: He love dogs.

\section{T: He loves dogs.}

Also, explicit correction is not anymore one type but exists in the form of the two types: explicit correction only (i.e., the correction takes the form of a direct signal that an error has been committed and the correct form is supplied), or explicit correction plus metalinguistic explanation (i.e. in addition to signalling an error has been committed and providing the correct form, there is also a metalinguistic comment).

Paralinguistic signal (i.e. non-verbal attempt to retrieve the correct form from the student), an under-researched feedback type not mentioned in Lyster and Ranta's 1997 and 2007 models, is now added in Sheen and Ellis's model. 
Besides the change in the number of individual OCF types, this taxonomy by Sheen and Ellis uses two new terms, "inputproviding" and "output-prompting", which replace "reformulations" and "prompts", respectively, coined by Lyster and Ranta.

The last but important new theoretical aspect of this taxonomy is the division of the nine feedback types according to their explicitness. This distinction, based on the salience and noticeability of CF to the learners, is between implicit CF where there is no overt signal that an error has been made, and explicit CF where there is a signal. Explicit feedback includes didactic recasts, explicit correction only, explicit correction with metalinguistic explanation, metalinguistic clues, elicitation, and paralinguistic feedback. Implicit feedback consists of conversational recasts, repetition, and clarification requests.

This implicit/explicit dichotomy does not bring contentment among SLA researchers, leading to the development of the most up-todate model by Lyster, Saito, and Saito (2013).

\subsection{Lyster, Saito, and Sato (2013)}

The most recent OCF classification model is one devised by Lyster, Saito, and Sato (2013) who further developed the previous models by adding the different single feedback moves on a continuum, rather than the dichotomy by Sheen and Ellis, of explicitness/implicitness, with reference to the dichotomy of reformulations and prompts (see Figure 1). At the furthest end of implicitness are recasts and clarification requests while at the explicit end are explicit correction and metalinguistic clue.

\section{PROMPTS}

\begin{tabular}{|c|c|c|c|c|c|}
\hline \multirow{3}{*}{ IMPLICIT } & $\begin{array}{l}\text { Clarification } \\
\text { request }\end{array}$ & Repetition & Paralinguistic signal & $\begin{array}{l}\text { Metalinguistic } \\
\text { clue }\end{array}$ & \multirow{3}{*}{$\rightarrow$ EXPLICIT } \\
\hline & 4 & & & 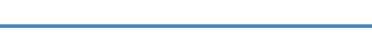 & \\
\hline & $\begin{array}{l}\text { Conversational } \\
\text { recasts }\end{array}$ & Didactic recast & Explicit correction & $\begin{array}{l}\text { Explicit correction }+ \\
\text { metalinguistic explanation }\end{array}$ & \\
\hline
\end{tabular}

REFORMULATIONS

Figure 1. Classification of OCF (Lyster et al., 2013)

From the four models, it can be seen that the classification of oral corrective feedback has become more and more detailed and comprehensive over time. The model by Lyster and Ranta (1997) started with a description of six single moves of feedback which were then categorised into two sub-groups, reformulations and prompts by Ranta and Lyster (2007). Later, the OCF types were discussed in terms of implicitness and explicitness in the model by Sheen and Ellis (2011), and then the model by Lyster, Saito, and Sato (2013) provided a more comprehensive picture with the addition of the implicitness/explicitness continuum. However, even with the development of comprehensive categorisations of OCF types, a number of issues remain, which are discussed below.

\section{Issues concerned}

\subsection{Recasts}

Numerous discussions have raised questions about the category that recasts fit into. Recasts are typically identified as implicit because there are no such introducing phrases as "You should say..." "You mean..." and "Use this word...". However, their degrees of salience are different, because it depends on 
whether it is a partial or a full recast, with or without emphasis/intonation.

Recasts were included in Lyster and Ranta (1997) but these were re-coded into four types by Lyster (1998, p. 54).

a. An isolated declarative recast which provides confirmation of a learner's message by correctly reformulating all or part of the utterance with falling intonation.

$\mathrm{S}$ : Avantque quelqu'un le prendra Before someone it willtake "Before someone will take it."

$\mathrm{T}$ : Avantque quelqu'un le prenne before someone it takes

"Before someone takes it."

b. An isolated interrogative recast seeks confirmation of the learner's message by correctly reformulating all or part of the utterance with rising intonation.

$\mathrm{S}$ : He is nurse.

$\mathrm{T}$ : a nurse?

c. An incorporated declarative recast provides additional information by incorporating the correct reformulation of all or part of a learner's utterance into a longer statement.

\section{$\mathrm{S}:$ He is nurse.}

T: Yes, that's true that he is a nurse but he also works in a farm.

d. An incorporated interrogative recast seeks additional information by incorporating the correct reformulation of all or part of a learner's utterance into a question.

\section{S: He needs umbrella.}

\section{$\mathrm{T}$ : Why does he need an umbrella?}

Recasts have been the most difficult CF type to categorise in terms of explicitness and implicitness. Because of their complexity, recasts have attracted a great deal of attention in SLA research. There has been a consensus on the continuum of their implicitness; recasts can be more or less implicit depending on the context, linguistic targets, length of the utterance, and the changes made to the utterance (Ellis \& Sheen, 2006; Lyster, Saito, \& Sato, 2013; Nicholas, Lightbown, \& Spada, 2001; Sato, 2011; Sheen, 2004; Sheen, 2006). For example, long recasts with a number of changes have been thought to reduce the student's noticing of correction (Egi, 2007). Recasts are thought to be more salient and noticeable when the learners focus more on the language form than on communication (Oliver \& Mackey, 2003), or less salient with morpho-syntactic targets (Mackey, Gass, \& McDonough, 2000). They have been found to be more noticeable to an L1 than to another, e.g. more noticeable to Japanese than Canadian students (Lyster \& Mori, 2006). Recasts have been found to repair as much as explicit correction does, so are considered equivalent to explicit correction in some studies (Lochtman, 2002; Loewen \& Nabei, 2007); however, they have been found to cause a lower level of repair in uptake than explicit correction in others (Lyster, 1998; Sheen, 2004). Intensive recasts (that is recasts on errors of one type) have been found more effective than extensive recasts (that is recasts on errors of all types) (Nassaji, 2017).

Clearly, the results from these studies are mixed and it is evident that the difference in the way recasts are operationalised may affect their effectiveness. According to Lyster, Saito, and Sato (2013), although recasts vary in terms of their levels of implicitness, recasts belong to the implicit end of the continuum (see Figure 1). In contrast, Sheen and Ellis (2011) seem to have considered recasts as a dichotomy of implicitness and explicitness when they divide recasts into two subtypes. Conversational recasts are thought implicit and didactic recasts explicit. 
This ambiguity requires researchers to justify their categorisation of recasts, and to design instruments that match their definition and classification. As cautioned by Ellis, Loewen, and Erlam (2006), a generalisation of the findings in relation to recasts needs to be done with care, taking into account all the differences in purpose and design of the studies. From the discussion above, it is evident that explicitness of recasts is a difficult variable to hold constant in all contexts since it depends on a variety of factors. For this reason, it is necessary to identify the type of recasts employed in research studies.

\subsection{Other OCF types}

As stressed above, recasts vary in their levels of implicitness. Contentious issues have arisen in terms of other OCF types also. First, there is the complexity with regards to the explicitness level of explicit correction which can be used with or without metalinguistic explanation. Another noticeable feature is that, while elicitation is considered explicit by most of SLA researchers (Ellis, 2009; Loewen \& Nabei, 2007; Lyster, Saito, \& Sato, 2013; Sheen \& Ellis, 2011), it is classified as implicit by Li (2010, p. 323) who follows Carroll and Swain's (1993, p. 365) definition of a CF as implicit because subjects are "never told directly that they were wrong, and they have to infer in order to understand their interlocutor's behaviour". Also, metalinguistic feedback has different degrees of informativeness (Lyster, 2015). It can consist of metalinguistic clues which simply provide a negator to reject the incorrect utterance of learners (e.g. No, not "has cat"), or it can entail metalinguistic explanation (e.g. You need an article " $a$ ", "an" or "the" before a noun). This feedback can be a combination of metalinguistic clues and explanation, which constitutes a higher degree of informativeness of the feedback and so increases its explicitness.

\section{Conclusion}

The classification of OCF have evolved over time through the works of prominent researchers. The number of OCF has increased, from the first time identified as six single types (Lyster \& Ranta, 1997; Ranta \& Lyster, 2007), and later, nine types in Sheen and Ellis's (2011) model. Moreover, these single CF moves are categorised based on reformulations/prompts or input-providing/output-prompting, and also implicit/explicit dichotomy. The implicit/ explicit continuum of the OCF types is the latest feature added to the most up-to-date model by Lyster, Saito, and Sato (2013).

With the aim to review and provide more information on OCF for ESL/EFL teachers in general and in Vietnam, particularly, the author hopes that there will be more teacher inquiries into this specific area in SLA, and more training on the matter will be carried out.

Theoretically, as mentioned in the Introduction above, the different ways of classifying or viewing OCF types affect the SLA researchers' perspectives in their studies into the effectiveness of OCF, substantially evidenced by a great volume of research. The author can discuss the relation between the application of different OCF classification models and the results of research into the effectiveness of OCF in the coming paper.

\section{References}

Carroll, S., \& Swain, M. (1993). Explicit and implicit negative feedback: An empirical study of the learning of linguistic generationalizations. Studies in Second Language Acquisition, 15, 357-386.

Chaudron, C. (1977). A descriptive model of discourse in the corrective treatment of learners' errors. Language Learning, 27, 29-46.

Egi, T. (2007). Interpreting recasts as linguistic evidence: The roles of linguistic target, length, and degree of change. Studies in Second Language Acquisition, 29(4), 511-537. doi: 10.1017/S0272263107070416

Ellis, R. (2009). Corrective feedback and teacher development. L2 Journal, 1, 3-18. 
Ellis, R. (2017). Oral corrective feedback in L2 classrooms: What we know so far. In H. Nassaji \& E. Kartchava (Eds.), Corrective feedback in second language teaching and learning: Research, theory, applications, implications (pp. 19-36). New York, NY: Routledge. Retrieved from http:// ebookcentral.proquest.com/lib/canberra/detail. action? docID $=4838140$

Ellis, R., Loewen, S., \& Erlam, R. (2006). Implicit and explicit corrective feedback and the acquisition of L2 grammar. Studies in Second Language Acquisition, 28, 339-368.

Ellis, R., \& Sheen, Y. (2006). Re-examining the role of recasts in second language acquisition. Studies in Second Language Acquisition, 28(4), 575-600. doi: $10.1017 / \mathrm{S} 027226310606027 \mathrm{X}$

Gooch, R., Saito, K., \& Lyster, R. (2016). Effects of recasts and prompts on L2 pronunciation development: Teaching English $/ \mathrm{I} /$ to Korean adult EFL learners. System, 60, 117-127. doi: http:// dx.doi.org/10.1016/j.system.2016.06.007

Le, V. C. (2011). Form-focused instruction: A case study of Vietnamese teachers' beliefs and practices. Doctor of Philosophy (PhD) (Doctoral). University of Waikato, Hamilton, New Zealand. Retrieved from https://hdl.handle.net/10289/5253.

Li, S. (2010). The effectiveness of corrective feedback in SLA: A meta-analysis. Language Learning, 60(2), 309-365.

Lochtman, K. (2002). Oral corrective feedback in the foreign language classroom: How it affects interaction in analytic foreign language teaching. International Journal of Educational Research, 37(3-4), 271-283. doi: http://dx.doi.org/10.1016/ S0883-0355(03)00005-3

Loewen, S., \& Nabei, T. (2007). Measuring the effects of oral corrective feedback on L2 knowledge. In A. Mackey (Ed.), Conversational interaction in second language acqusition: A series of empirical studies (pp. 361-377). United Kingdom: Oxford University Press.

Lyster, R. (1998). Recasts, repetition, and ambiguity in L2 classroom discourse. Studies in Second Language Acquisition, 20(1), 51-81.

Lyster, R. (2015). The relative effectiveness of corrective feedback in classroom interaction. In N. Markee (Ed.), The handbook of classroom discourse and interaction (1st ed., pp. 221-228). Malden, MA: Wiley-Blackwell.

Lyster, R., \& Mori, H. (2006). Interactional feedback and instructional counterbalance. Studies in Second Language Acquisition, 28(2), 269-300. doi: 10.1017/ S0272263106060128

Lyster, R., \& Ranta, L. (1997). Corrective feedback and learner uptake. Studies in Second Language Acquisition, 19(1), 37-66.

Lyster, R., \& Saito, K. (2010). Oral corrective feedback in classroom SLA: A meta-analysis. Studies in Second Language Acquisition, 32(Special Issue 2), 265-302. doi: 10.1017/S0272263109990520
Lyster, R., Saito, K., \& Sato, M. (2013). Oral corrective feedback in second language classrooms. Language Teaching, 46(1), 40. doi: 10.1017/ S0261444812000365

Mackey, A., Gass, S., \& McDonough, K. (2000). How do learners perceive interactional feedback? Studies in Second Language Acquisition, 22(4), 471-497.

Nassaji, H. (2017). The effectiveness of extensive versus intensive recasts for learning L2 grammar. The Modern Language Journal, 101(2), 353-368. doi: $10.1111 / \operatorname{modl} .12387$

Nguyen, N. M. (2003). Error correction revisited. Retrieved from http://www.nzdl.org/gsdlmod? $\mathrm{e}=\mathrm{d}-$ 00000-00---off-0literatu--00-0----0-10-0---0--0direct-10---4-------0-11--11-en-50---20-about---000-1-00-0--4----0-0-11-10-0utfZz-8-00\&a=d\&c=lite ratu\&cl $=\mathrm{CL} 1.5 \& \mathrm{~d}=\mathrm{HASH} 016790793 \mathrm{a} 8 \mathrm{~d} 8 \mathrm{ce} 5824 \mathrm{c}$ $852 \mathrm{f}$

Nicholas, H., Lightbown, P. M., \& Spada, N. (2001). Recasts as feedback to language learners. Language Learning, 51(4), 719.

Oliver, R., \& Mackey, A. (2003). Interactional context and feedback in child ESL classrooms. The Modern Language Journal, 87(4), 519-533. doi: 10.1111/1540-4781.00205

Pham, T. H. (2018). Relative effects of oral corrective feedback combined with explicit instruction on EFL learner's pragmatic competence. $\mathrm{PhD}$ (Unpublished). University of Canberra.

Ranta, L., \& Lyster, R. (2007). A cognitive approach to improving immersion students' oral language abilities: The awareness-practice-feedback sequence. In R. M. Dekeyser (Ed.), Practice in second language: Perspectives from applied linguistics and cognitive psychology (pp. 141-160). New York, NY: Cambridge University Press.

Sato, M. (2011). Constitution of form-orientation: Contributions of context and explicit knowledge to learning from recasts. Canadian Journal of Applied Linguistics, 14(1), 1-28.

Sheen, Y. (2004). Corrective feedback and learner uptake in communicative classrooms across instructional settings. Language Teaching Research, 8(3), 263-300.

Sheen, Y. (2006). Exploring the relationship between characteristics of recasts and learner uptake Language Teaching Research, 10(4), 361-392. doi: http://dx.doi.org/10.1191/1362168806lr203oa

Sheen, Y., \& Ellis, R. (2011). Corrective feedback in language teaching. In E. Hinkle (Ed.), Handbook of research in second language teaching and learning (Vol. 2, pp. 593-610). New York, NY: Routledge.

Truscott, J. (1996). The case against grammar correction in L2 writing class. Language Learning, 46(2), 327-369.

Yang, Y., \& Lyster, R. (2010). Effects of form-focused practice and feedback on Chinese EFL learners' acquisition of regular and irregular past tense. Studies in Second Language Acquisition, 32(Special issue 2), 235-263. 


\title{
HÌNH THỨC CHŨ'A LỖI BẰNG LỜI NÓI TRONG LỚP HỌC NGOẠI NGỮ: CÁC MÔ HİNH PHÂN LOẠI
}

\author{
Phạm Thị Hạnh, Phạm Xuân Thọ \\ Khoa Ngôn ngũ và Văn hóa các nước nói tiếng Anh, Trường Đại học Ngoại ngũu, ĐHQGHN, \\ Phạm Văn Đồng, Cầu Giấy, Hà Nội, Việt Nam
}

Tóm tắt: Chữa lỗi nói chung, và chữa lỗi bằng lời nói nói riêng, từ lâu đã là mối quan tâm đặc biệt của cả giáo viên và các nhà nghiên cứu trong lĩnh vực giảng dạy ngoại ngữ. Giáo viên tập trung nhiều hơn tới cách đưa ra phản hồi tích cực nhằm khuyến khích người học, đồng thời quan tâm tới câu hỏi liệu có nên chữa lỗi, và nếu có thì chữa vào thời điểm nào và bằng cách nào. Theo hướng khác, các nhà nghiên cứu trong lĩnh vực thụ đắc ngoại ngữ quan tâm tới việc đưa ra phản hồi trực tiếp vào lỗi của người học và tính hiệu quả của các hình thức chữa lỗi này. Đã có nhiều mô hình phân loại các hình thức chữa lỗi bằng lời nói dựa trên các tiêu chí khác nhau, ví dụ: chữa lỗi một cách hàm ẩn hay rành mạch, hoặc dựa vào tiêu chí cung cấp hay không cung cấp mẫu ngôn ngữ khi người học mắc lỗi. Bài viết này sẽ tổng hợp một số mô hình nổi trội trong việc phân loại các hình thức chữa lỗi bằng lời nói trong lĩnh vực thụ đắc ngoại ngữ.

Tù khóa: chữa lỗi bằng lời nói, mô hình phân loại, giảng dạy ngoại ngữ 